\title{
Natural balance of graminicolous aphids in Pakistan II. - Aphids populations on maize
}

Sulaiman HAMID

Sind Sugar Industry Research Institute, 14/A, Latifabad III, Hyderabad Sind, Pakistan

Maize in Pakistan is attacked by Myzus obtusirostris David, Narayanan \& Rajasingh, Rhopalosiphum padi (L.) and Sipha maydis (Pass.). M. obtusirostris occurs only in the hills, and has comparatively higher populations in the Kaghan valley $(1,800-2,100 \mathrm{~m})$ than in the Murree hills $(2,000 \mathrm{~m})$ but is short lived in the Swat valley $(1,800 \mathrm{~m})$. Although Coccinella septempunctata $\mathrm{L}$. and Menochilus sexmaculatus $\mathrm{F}$. were encountered, predation by Episyrphus balteatus (De Geer), E. confrater (Wied.) and Chrysopa carnea Stephens was the important mortality factor. In addition to these predators, aphids in the Swat valley were also attacked by Oenopia sauzeti Muls., Scymnus sp., the anthocorid Orius sp. and a forficulid. Lysiphlebus arvicola Stary parasitized $M$. obtusirostris in the Kaghan valley while Aphelinus sp. parasitized S. maydis in the Swat valley.

Additional key words : Population dynamic, natural enemies, parasite, predator.

Equilibre naturel chez les pucerons des graminées au Pakistan. II. - Populations d'aphides en culture de maïs.

Au Pakistan, le maïs est attaqué par Myzus obtusirostris David, Narayanan \& Rajasingh, Rhopalosiphum padi (L.) et Sipha maydis Pass.

$M$. obtusirostris se rencontre seulement en altitude : tandis que ses populations sont comparativement plus abondantes dans la vallée de Kaghan $(1800 \mathrm{~m}$ à $2100 \mathrm{~m})$ que dans les monts Murree $(2000 \mathrm{~m})$, sa présence dans la vallée de Swat $(1800 \mathrm{~m})$ est toujours de courte durée.

Hormis l'activité de Coccinella septempunctata L. et de Menochilus sexmaculatus F., la prédation exercée par Episyrphus balteatus (De Geer), E. confrater (Wied.) et Chrysopa carnea Stephens représente le facteur de mortalité prépondérant.

Outre l'action de ces prédateurs, dans la vallée de Swat, les pucerons du maïs sont aussi l'objet du prédatisme exercé par Oenopia sauzeti Muls., Scymnus sp., des anthocorides du genre Orius et par un forficulide.

Lysiphlebus arvicola Stary parasite $M$. obtusirostris dans la vallée de Kaghan tandis que Aphelinus sp. parasite $S$. maydis dans la vallée de Swat.

Mots clés additionnels : Dynamique de population, ennemis naturels, parasite, prédateur.

\section{INTRODUCTION}

The natural balance and populations of 8 graminicolous aphids that occur in different ecological conditions of Pakistan has been reported quite recently and the relevant literature has thoroughly been reviewed (HAMID, 1983). In Southern England also, cereal aphids on maize have been studied in some details (HAND \& CARRILlo, 1982). Populations of Myzus obtusirostris David, Narayanan \& Rajasingh, Rhopalosiphum padi (L.), and Sipha maydis (Pass.) on maize as affected by natural enemies are reported.

\section{MATERIAL AND METHODS}

Populations were studied at Kaghan (altitude $1,800 \mathrm{~m})$ and Naran $(2,100 \mathrm{~m})$ in the Kaghan valley ;
Singota $(1,800 \mathrm{~m})$ in the Swat valley, and Bhurban $(2,000 \mathrm{~m})$ in the Murree hills, in the north west of Pakistan. Sampling methods already described (HAMID, 1983) were followed.

\section{POPULATION STUDIES}

\section{A. Kaghan valley}

The Kaghan valley is narrow and generally steepsided and maize is grown in very small plots. Areas of approximately half a hectare were marked at both Kaghan and Naran for the study. Since the cultivators did not allow the removal of plant samples observations were recorded in the area selected for this purpose during June-October 1973. 
M. obtusirostris was the most common aphid on maize. Both the infestation rates and populations were highest during September, and were higher at Naran than at Kaghan. The predators Episyrphus balteatus (De Geer) and E. confrater (Wied.) were associated with them at Kaghan, with the addition of Chrysopa carnea Stephens at Naran. The crop was harvested in October at Naran and a month later in Kaghan. Lysiphlebus arvicola Stary parasitized $0.2 \%$ of the aphids during June at Kaghan and $5 \%$ during July at Naran. During the course of study, Coccinella septempunctata L. was encountered at Naran in August, Menochilus sexmaculatus F. in September, and at Kaghan C. septempunctata and M. sexmaculata during October.

At Naran S. maydis was collected during August and September and $R$. padi during September while at Kaghan the 2 aphids were found during October.

In the Kaghan valley $M$. obtusirostris was the dominant aphid on maize. Predation was an important mortality factor. At Kaghan the predator complex was more diverse and the amount of predation was greater than Naran, which is about $300 \mathrm{~m}$ higher. The low rate of $L$. arvicola parasitism may be due to the short season and low aphid population.

\section{B. Murree hills}

M. obtusirostris was also noticed on the cooler sides of the Murree hills and populations were studied in 2 adjacent fields on the hill slope at Bhurban during 1974. The upper plot was exposed to the sun while the lower was under the shade of a row of poplar trees.

Fortnightly observations during May-September indicated that infestation in the sunny plot started in May, but the number of plants attacked and the aphid population remained very low till July. Subsequently an upward trend in population growth and a peak of 978 aphids per 50 plants was recorded in midSeptember, when the infestation was $40 \%$ and the plant height $(275 \mathrm{~cm})$ became constant (fig. 1).

Infestation in the shady plot appeared only in July. Both infestation and rate of population growth were low and there was no parasitism during August.

$E$. balteatus and $C$. carnea appeared in the shady plot and $C$. carnea in the sunny plot during August. Both the predators were active in September in these plots. Parasitism by $L$. arvicola was recorded only during September in the sunny plot.

It appeared that shady plots do not develop the same population as sunny plots, although $M$. obtusirostris is present in all the areas of the Murree hills.

\section{Swat valley}

During 1976, infestation on maize by $S$. maydis started in June when only few winged forms were seen on 50 plant counts ; 2,18 and 12 plants harboured 255 , 712 and 153 aphids during July, August and September, respectively (fig. 2). M. obtusirostris was encountered only during July and August in still smaller numbers. Episyrphus spp., C. septempunctata, M. sexmaculatus, Oenopia sauzeti Muls., Scymnus sp.,
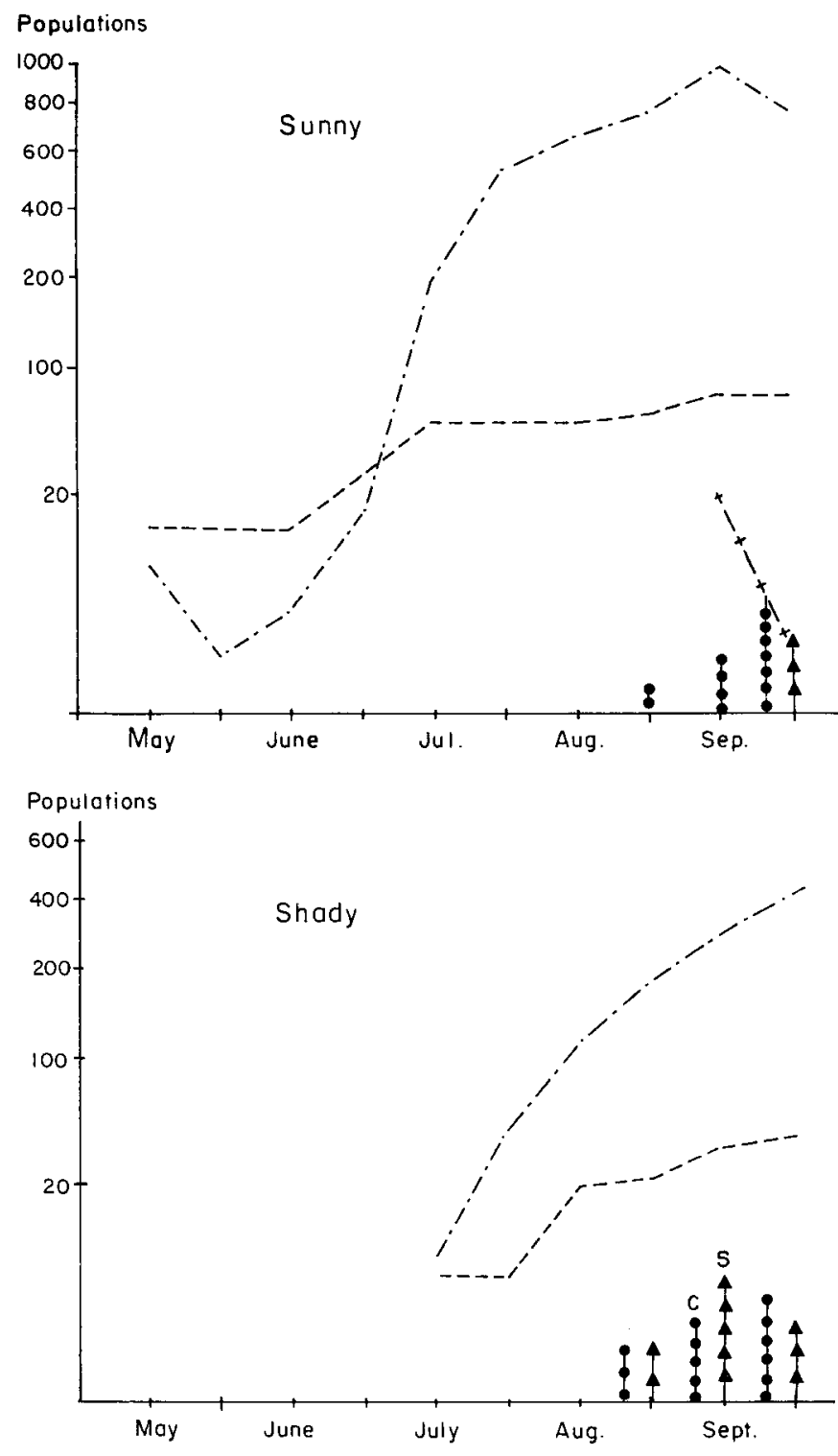

Figure 1

Myzus obtusirostris populations on maize at Bhurban, 1974. (Aphids per 50 plants - predators per 500 aphids).

Populations de Myzus obtusirostris sur maïs, à Bhurban, 1974. (Pucerons pour 50 plantes, prédateurs pour 500 pucerons).

$$
\begin{array}{rr}
\times-\times=\% \text { parasitism } & -\cdot \cdot \cdot=\text { Aphid population } \\
\bullet \mathrm{C}=\text { Chrysopa carnea } & \Delta \mathrm{S}=\text { Episyrphus spp. }
\end{array}
$$

the anthocorid Orius sp. and a forficulid preyed upon these and the parasite Aphelinus sp. was also recorded. The predators apparently played a major role in keeping the population at a very low level.

\section{DISCUSSION AND CONCLUSION}

Since maize is now grown for edible oil and high fructose syrup in addition to usual cereals and animal feeds under diversified conditions, there is a general interest in the pests of this crop. The area under maize has increased world wide, and in Pakistan alone, it has increased by 104100 hectares during the last decade. Maize is grown everywhere in Pakistan and up to 3 crops of fodder and 2 of grain per year are 

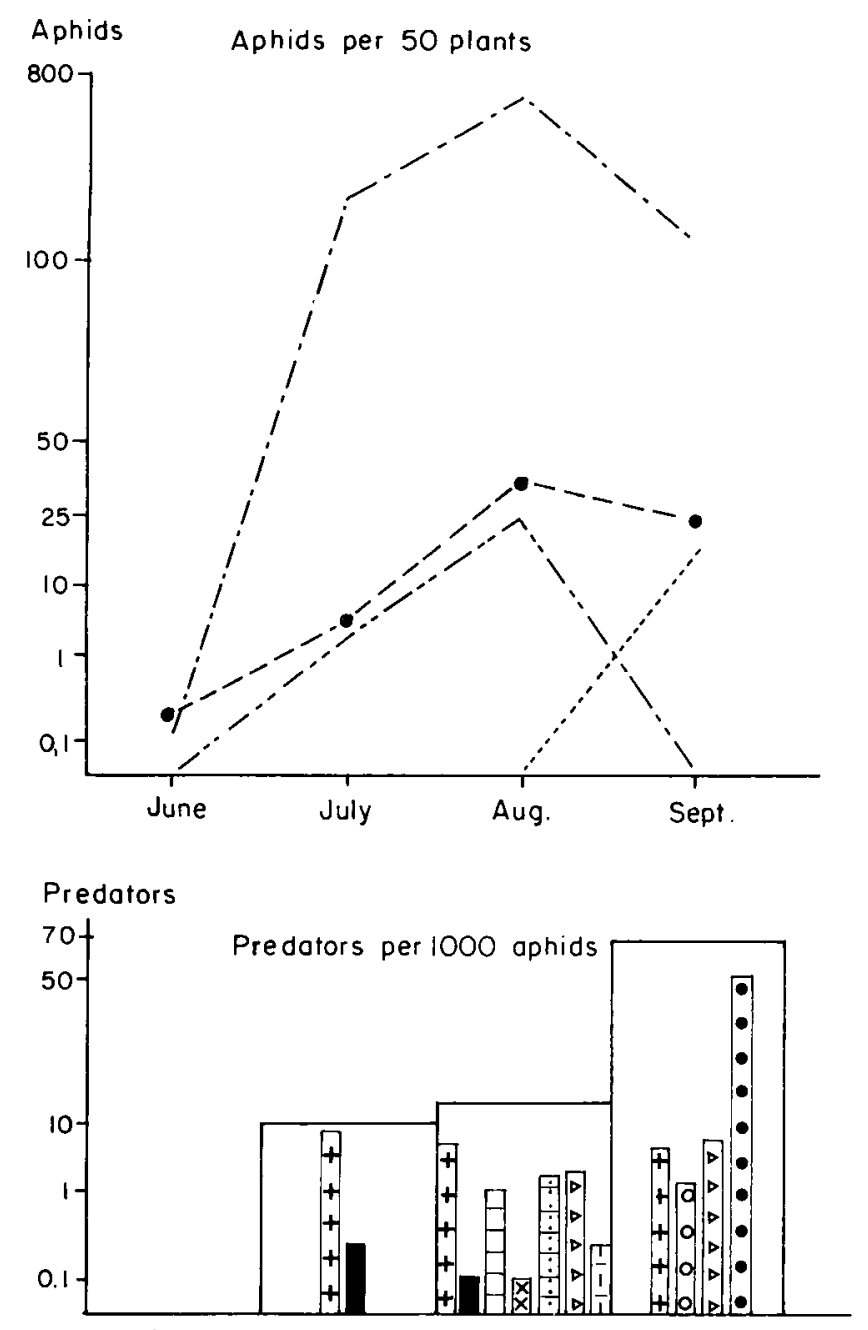

Figure 2

Aphid populations on maize in Swat, 1976.

Populations aphidiennes sur mais dans la vallée de Swat, 1976.

$\begin{aligned} & \cdots \cdots=\% \text { parasitism } \\ &-\cdots+\cdot=\text { Myzus obtusirostris }\end{aligned}$

$\mathbf{I}=$ Menochilus sexmaculatus

图= Pullus sp.

- Orius sp.

E = Oenopia sauzeti

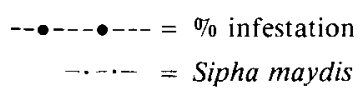

专 = Episyrphus spp.

目 $=$ Coccinella septempunctata

固 = Harmonia dimidiata

] = Chrysopa carnea

[. Forficulid harvested. Although much work has been done on corn borers throughout the world, information on aphids attacking maize is comparatively scarce, and it is here that this paper makes its contribution.

The aphid fauna associated with maize in Pakistan is comparatively small. Six species of graminicolous aphids have been reported from England (HAND \& CARRILlo, 1982). Rhopalosiphum maidis (Fitch) which is the main aphid species in the USA (CHIANG, 1978) was not encountered on maize in Pakistan. $S$. maydis is common throughout Pakistan. $R$. padi is common to wheat and maize in the hills, while $M$. obtusirostris is restricted to high altitudes only (HAMID, 1979). M. obtusirostris has so far been reported from unidentified grasses from hill stations in Himachal Paradesh and Uttar Paradesh in India (DAVID et al., 1971).

Predation was the main mortality factor, found to be due to an anthocorid, 1 chrysophid, 5 coccinellids, 1 forficulid and 2 syrphids. The complex was strongest at Swat and followed a definite sequence as compared to Kaghan valley and Murree hills. Of the predators, the chrysophid and the syrphids were important and occurred commonly throughout Pakis$\tan$.

$L$. arvicola that attacked $M$. obtusirostris in the hills has also been reported from $S$. maydis and $R$. padi (MACKAUER \& STARY, 1967). Despite low parasitism which seemingly resulted from a short period of activity, $L$. arvicola appears an appropriate parasite to be considered for introduction in areas of complex aphid infestation in cooler climatic zones.

\section{Reçu le 11 avril 1983.} Accepté le 4 mai 1984

\section{ACKNOWLEDGEMENT}

This work formed a portion of research conducted at Commonwealth Institute of Biological Control Rawalpindi under a project financially supported by United States Department of Agriculture.
Chiang H. C., 1978. Pest management in Corn. Annu. Rev. Entomol., 23, 101-103.

David S. K., Narayanan K., Rajasingh S. G., 1971. A new genus and four new species of aphids (Homoptera) from India. Oriental Insects, $5(4), 557-570$.

Hamid S., 1979. Some biological, ecological and behavioural studies on the natural balance of graminaceous aphids in Pakistan. Ph. D. thesis in Quaid-e-Azam University, Islamabad, 1-132.
Hamid S., 1983. Natural balance of graminicolous aphids in Pakistan I. Survey and populations. Agronomie, 3 (7), 665-673.

Hand S. C., Carrillo J. R., 1982. Cereal aphids on maize in southern England. Ann. Appl. Biol., 100, 39-47.

Mackauer M., Stary P., 1967. World Aphidiidae (Hym. : Ichneumonidae), in "Index of Entomophagous Insects" Ed. Delucchi, V. \& G. Remaudiere, Le François, Paris, 195 p. 